\title{
Carbon-Phosphorus Hydrolase: Some Properties of the Enzyme in Cell Extracts of Enterobacter aerogenes
}

\author{
Kousaku Murata, ${ }^{*}$ Noriko HigaKi and Akira Kimura \\ Research Institute for Food Science, Kyoto University, \\ Uji, Kyoto 611, Japan
}

Received September 29, 1988

\begin{abstract}
Cells of Enterobacter aerogenes IFO 12010 could grow on a medium containing alkylphosphonic acids as sole sources of phosphorus. The formation of the enzyme responsible for the liberation of inorganic phosphate (Pi) from alkylphosphonic acids was induced when Pi-grown cells were transferred to a medium containing no added $\mathrm{Pi}$. The extracts prepared from cells after incubation in the absence of $\mathrm{Pi}$ showed high carbon-phosphorus $(\mathrm{C}-\mathrm{P})$ bond cleavage activity and catalyzed the liberation of $\mathrm{Pi}$ from alkylphosphonic acids most efficiently in the alkaline $\mathrm{pH}$ region. We named the enzyme $\mathrm{C}-\mathrm{P}$ hydrolase, tentatively.
\end{abstract}

Despite extensive studies on the distribution of alkylphosphonic acids in living systems and their utilization by microorganisms as phosphorus 'sources, ${ }^{1 \sim 7)}$ the activity of a carbonphosphorus (C-P) bond cleavage enzyme had not been detected hitherto in a cell-free system, and further progress in the biochemistry of alkylphosphonic acids is greatly dependent on the detection of cell-free activity.

In order to obtain microbial strains with high $\mathrm{C}-\mathrm{P}$ bond cleavage activity, we screened bacterial strains that are capable of accumulating inorganic phosphate $(\mathrm{Pi})$ in culture medium containing phosphonoacetic acid. ${ }^{9)}$ Among forty bacterial strains tested, two (Bacillus roseus AKU 0208 and Enterobacter aerogenes IFO 12010) were found to accumulate substantial amounts of $\mathrm{Pi}$ in the culture medium, possibly due to the cleavage of the $\mathrm{C}-\mathrm{P}$ bond in phosphonoacetic acid, and we detected, for the first time, $\mathrm{C}-\mathrm{P}$ bond cleavage activity in cell-free extracts of Enterobacter aerogenes IFO 12010.9)

The present study was undertaken to obtain further information on the $\mathrm{C}-\mathrm{P}$ bond cleavage enzyme in Enterobacter aerogenes IFO 12010.

\footnotetext{
* To whom correspondence should be addressed.
}

\section{Materials and Methods}

Cultivation and preparation of cell extracts. Cells of Enterobacter aerogenes IFO 12010 were grown in $100 \mathrm{ml}$ of medium D [ $0.5 \%$ glucose, $0.1 \%\left(\mathrm{NH}_{4}\right)_{2} \mathrm{SO}_{4}, 0.01 \%$ $\mathrm{MgSO}_{4} \cdot 7 \mathrm{H}_{2} \mathrm{O}, 0.005 \%$ yeast extract (Pi-free) and $30 \mathrm{~mm}$ $N$-(2-hydroxyethyl)piperazine- $N^{\prime}$-2-ethanesulfonic acid (HEPES), $\mathrm{pH}$ 7.2] supplemented with various phosphorus sources. Yeast extract (Pi-free) was prepared by magnesia treatment ${ }^{10}$ and contained no detectable Pi. Alkylphosphonic acids were filter-sterilized before use. Glassware was rinsed with nitric acid to minimize Pi contamination. Cultivation was carried out in $5 \mathrm{dl}$ Sakaguchi flasks at $30^{\circ} \mathrm{C}$ with reciprocation $(120 \mathrm{rpm}, 3 \mathrm{~cm}$ stroke). When the turbidity of a culture reached 0.7 (O.D. at $610 \mathrm{~nm}$ ), the cells were collected, washed once in $20 \mathrm{ml}$ of $10 \mathrm{~mm}$ Tris- $\mathrm{HCl}$ buffer (pH 7.5) containing $0.5 \mathrm{mM} \mathrm{MgCl}_{2}$ [Tris $/ \mathrm{Mg}$ ], and then disrupted ultrasonically at $90 \mathrm{kHz}$ and $0^{\circ} \mathrm{C}$ for $5 \mathrm{~min}$. The homogenate was centrifuged at $25,000 \times g$ for $30 \mathrm{~min}$ and the resulting supernatant was used as an enzyme source after dialysis against Tris/ $\mathrm{Mg}$ at $4^{\circ} \mathrm{C}$ overnight.

Enzyme assays. C-P bond cleavage enzyme activity was assayed in a mixture $(0.5 \mathrm{ml})$ comprising $50 \mathrm{~mm}$ alkylphosphonic acid, $20 \mathrm{~mm} \mathrm{MgCl}_{2}, 50 \mathrm{~mm}$ Tris- $\mathrm{HCl}$ buffer $(\mathrm{pH}$ 7.5) and cell extract $\left(10 \mathrm{mg} / \mathrm{ml}\right.$ protein) at $37^{\circ} \mathrm{C}$ for $1 \mathrm{hr}$. The reaction was started by adding the cell extract and terminated by the addition of $0.5 \mathrm{~m} 1$ of $25 \%$ trichloroacetic acid. The mixture was centrifuged and then $\mathrm{Pi}$ in the clear solution was determined by the method of Fiske and Subbarow. ${ }^{11}$ Alkaline phosphatase was assayed in a mixture $(1.0 \mathrm{ml})$ consisting of $10 \mathrm{~mm} p$-nitrophenylphosphate, 
$20 \mathrm{mM} \mathrm{MgCl}_{2}$ and $50 \mathrm{~mm}$ Tris- $\mathrm{HCl}$ buffer ( $\mathrm{pH} 8.0$ ). The reaction was initiated by the addition of the cell extract and then the increase in absorbance at $412 \mathrm{~nm}$ was recorded at $25^{\circ} \mathrm{C}$. One unit of enzyme activity was defined as the amount liberating $1.0 \mu \mathrm{mol}$ of Pi per hour. Protein was determined according to the method of Lowry et al. ${ }^{12)}$

Cell transfer experiment. Cells were grown in Medium D ( $600 \mathrm{ml}$ in a 2 I Sakaguchi flask) supplemented with $5.0 \mathrm{~mm}$ Pi at $30^{\circ} \mathrm{C}$ with reciprocation, as above. When the turbidity of a culture reached 0.7 (O.D. at $610 \mathrm{~nm}$ ), the cells were collected, washed once in $20 \mathrm{ml}$ of $0.85 \%$ saline solution and then transferred to a $5 \mathrm{dl}$ Sakaguchi flask containing $100 \mathrm{ml}$ of Medium D or Medium D supplemented with $5.0 \mathrm{~mm}$ Pi or $1.0 \mathrm{~mm}$ phosphonoacetic acid. The initial cell concentration was adjusted to $7.0 \times 10^{8} / \mathrm{ml}$. After incubation for several hours at $30^{\circ} \mathrm{C}$ with reciprocation, the cells were collected and cell extracts were prepared as above.

Column chromatographies. Cells were grown on 151 of Medium D [1500 $\mathrm{ml}$ in a 21 Sakaguchi flask] supplemented with $0.3 \%$ phenylphosphonic acid at $30^{\circ} \mathrm{C}$ with reciprocation for $24 \mathrm{~h}$ and then cell extracts were prepared as before. Glycerol was added to each extract to a final concentration of $30 \%$ and then the extract was dialyzed against Tris $/ \mathrm{Mg}$ containing $30 \%$ glycerol [Tris $/ \mathrm{Mg} / \mathrm{Gly}$ ] at $4^{\circ} \mathrm{C}$ overnight. The dialysate was applied to a DEAEcellulose column $(4 \mathrm{~cm} \times 32 \mathrm{~cm})$ equilibrated with Tris/ $\mathrm{Mg} / \mathrm{Gly}$ and proteins were eluted with a linear gradient of $\mathrm{KCl}$, from 0 to $0.6 \mathrm{M}$ (total volume, $1300 \mathrm{ml}$ ) in the same buffer system. $7 \mathrm{ml}$ fractions were collected per $7 \mathrm{~min}$. The C-P bond cleavage enzyme fractions (Fraction Nos. $60 \sim 91$ ) were pooled and then concentrated to $30 \mathrm{ml}$ by ultrafiltration with an Amicon PM10 membrane. The concentrate was then loaded onto a Sephadex G-150 column $(2.5 \mathrm{~cm} \times 90 \mathrm{~cm})$ equilibrated with Tris $/ \mathrm{Mg} / \mathrm{Gly}$. Proteins were eluted with the same buffer and $4 \mathrm{ml}$ fractions were collected per $25 \mathrm{~min}$.

Chemicals. Methylphosphonic acid, phosphonoacetic acid and phenylphosphonic acid were purchased from Aldrich Chem. Co., Milw. Phosphonomycin was from Sigma Chemical, St. Louis, MO. Glyphosate was kindly supplied by Monsanto Japan Co., Ltd., Ryugasaki, Japan.

\section{Results and Discussion}

Utilization of alkylphosphonic acids as phosphorus sources

The utilization of alkylphosphonic acids by E. aerogenes IFO 12010 cells as sole sources of phosphorus was examined by cultivating cells in Medium D supplemented with various alkylphosphonic acids (Fig. 1). In the absence of

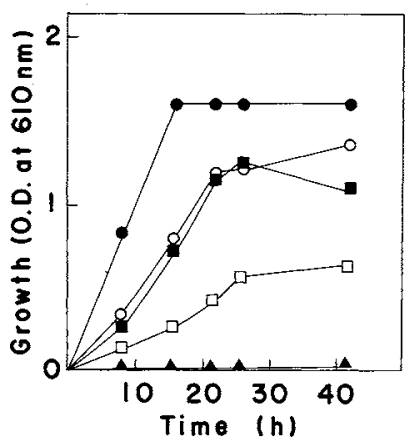

Fig. 1. Utilization of Alkylphosphonic Acids as Sole Sources of Phosphorus.

Cells were cultured in Medium D supplemented with various phosphorus sources, at $1.0 \mathrm{~mm}$. - $\mathbf{A}$ - none; - - orthophosphate; - $\mathrm{O}-$, methylphosphonic acid; - - - phosphonoacetic acid; - $\square-$, phenylphosphonic acid.

phosphorus source, slight growth was observed, that could be explained by phosphorus contamination of Medium D. Substantial growth was observed when various alkylphosphonic acids were added to the medium, at $1.0 \mathrm{~mm}$. The cells showed faster growth on Pi than on any of the alkylphosphonic acids tested. During growth on phenylphosphonic acid, the cells formed clumps and so accurate turbidimetric determination of growth was impossible, the reason for the aggregation of cells being not clear yet (Fig. 2). The poor growth of cells on phenylphosphonic acid may be partly attributable to this aggregation. The results of the growth experiment indicated that cells of E. aerogenes IFO 12010 could utilize alkylphosphonic acids as sole sources of phosphorus and the cells contained an enzyme that catalyzes the cleavage of the $\mathrm{C}-\mathrm{P}$ bonds in alkylphosphonic acids.

\section{Inducibility of the $C-P$ bond cleavage enzyme}

When cells of Enterobacter aerogenes IFO 12010 were grown on Medium D supplemented with $5.0 \mathrm{~mm} \mathrm{Pi}$, the extracts showed no detectable $\mathrm{C}-\mathrm{P}$ bond cleavage enzyme activity, i.e., no liberation of $\mathrm{Pi}$ from phosphonoacetic acid (data not shown). This suggested that the enzyme is inducible and that its formation is dependent on the cellular Pi concentration. In 
A
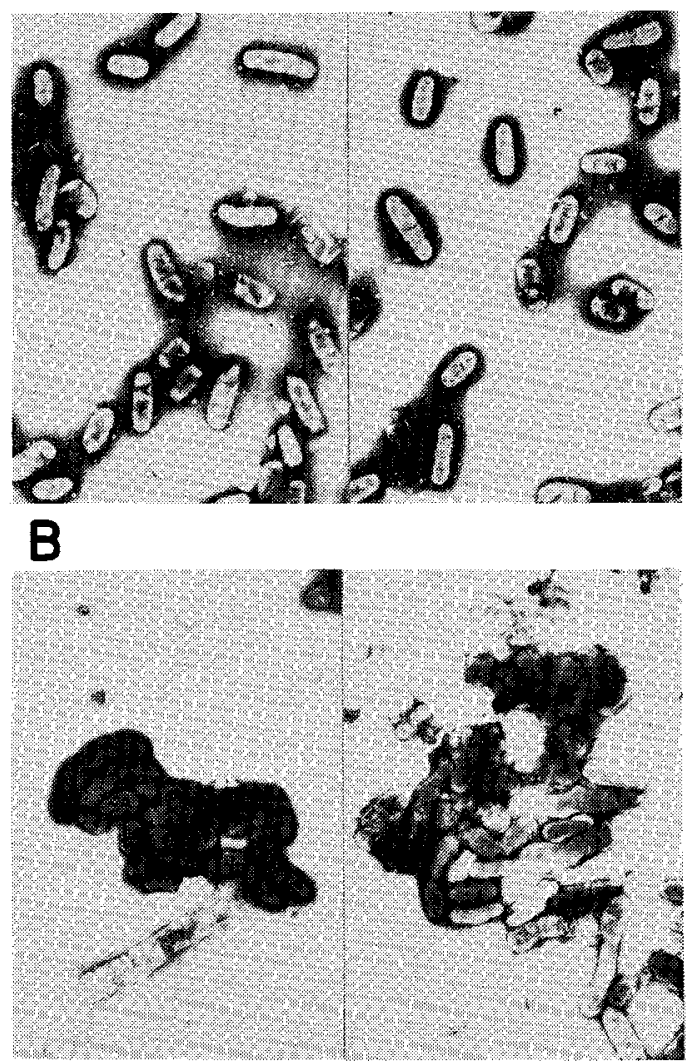

$(x 4000)$

Fig. 2. Cell Aggregation during Growth on Phenylphosphonic Acid.

The culture conditions were the same as those in the legend to Fig. 1. The photographs were taken after $30 \mathrm{hr}$ incubation. [A] orthophosphate-grown cells; [B] phenylphosphonic acid-grown cells.

order to confirm the inducibility of the enzyme, a cell transfer experiment was carried out as described under Materials and Methods (Fig. 3). The C-P bond cleavage enzyme activity remarkably increased when $\mathrm{Pi}$-grown cells were transferred to Medium D (Pi-free) or Medium D supplemented with $1.0 \mathrm{~mm}$ phosphonoacetic acid. The induction of the enzyme in medium containing phosphonoacetic acid was almost one-half that in medium containing no added $\mathrm{Pi}$. This is presumably due to the repression by $\mathrm{Pi}$ formed from phosphonoacetic acid by the enzyme induced. On the other

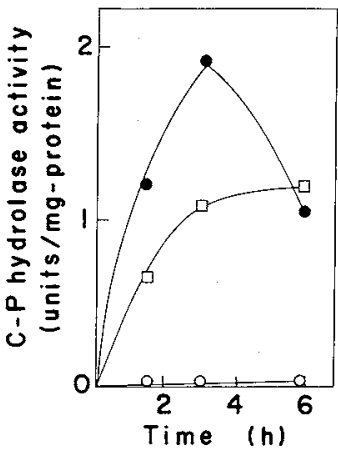

Fig. 3. Induction of the C-P Bond Cleavage Enzyme. Orthophosphate (Pi)-grown cells were transferred to Medium D (@) or Medium D supplemented with $1.0 \mathrm{~mm}$ phosphonoacetic acid ( $\square$ ) or $5.0 \mathrm{~mm} \mathrm{Pi}(O)$. After incubation for several hours, the activity of the C-P bond cleavage enzyme was determined with phosphonoacetic acid as a substrate. Other conditions were as given for the "Cell transfer experiment" under Materials and Methods.

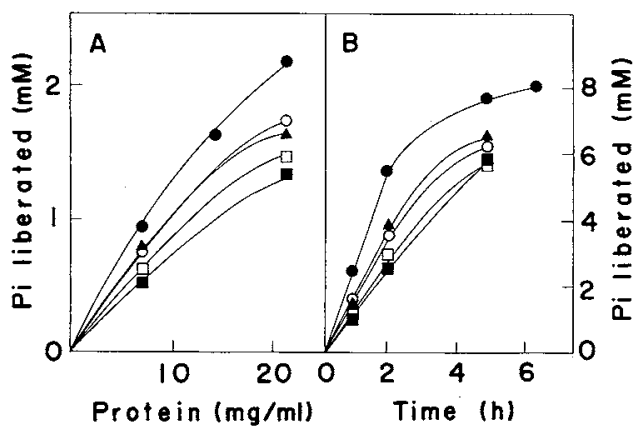

Fig. 4. Liberation of Inorganic Phosphate (Pi) from Various Alkylphosphonic Acids.

The reaction was carried out as described under Materials and Methods, except that the protein concentration and reaction time were varied. Pi liberated from alkylphosphonic acids is plotted as a function of the protein concentration $[\mathrm{A}]$ and the reaction time $[\mathrm{B}]$. - $\mathrm{O}-$, methylphosphonic acid $\left(\mathrm{CH}_{3}-\mathrm{PO}_{3}^{2-}\right) ;--0$, phosphonoacetic acid ( $\mathrm{HOOC}-\mathrm{CH}_{2}-\mathrm{PO}_{3}^{2-}$ ); - $\square-$, phenylphosphonic acid $\left(\mathrm{C}_{6} \mathrm{H}_{5}-\mathrm{PO}_{3}^{2-}\right)$; - - , glyphosate (HOOC- $\mathrm{CH}_{2}-\mathrm{NH}-\mathrm{CH}_{2}-\mathrm{PO}_{3}^{2-}-\mathbf{A}-$, phosphonomycin $\left(\mathrm{H}_{3} \mathrm{C}-\mathrm{CH}-\mathrm{CH}-\mathrm{PO}_{3}^{2-}\right)$.

hand, cells transferred to Medium D containing $5.0 \mathrm{~mm}$ Pi showed no increase in the enzyme activity. Thus, the enzyme catalyzing the $\mathrm{C}-\mathrm{P}$ bond cleavage is inducible, which supports the observation of Wackett et al. that the gene responsible for the $\mathrm{C}-\mathrm{P}$ bond cleavage 
enzyme is located in the Phosphate Starvation Inducible (PSI) regulon in Escherichia coli. ${ }^{13)}$

\section{$C-P$ bond cleavage enzyme activity in extracts of E. aerogenes}

Previously, we detected $\mathrm{C}-\mathrm{P}$ bond cleavage enzyme activity in extracts of $E$. aerogenes IFO 12010 cells grown on a medium containing phosphonoacetic acid as a sole source of phosphorus. ${ }^{9)}$ In order to compare the catalytic properties of the enzyme induced in the $a b$ sence of Pi with those of that formed in the presence of phosphonoacetic acid, Pi-grown cells were transferred to Medium D (Pi-free), to induce the $\mathrm{C}-\mathrm{P}$ bond cleavage enzyme, and then incubated for $3 \mathrm{hr}$ according to the procedures described for the cell transfer experiment under Materials and Methods. Extracts containing the induced enzyme were incubated with various alkylphosphonic acids, including a herbicide (glyphosate) and an antibiotic (phosphonomycin) (Fig. 4). The liberation of Pi from alkylphosphonic acids increased with both increasing protein concentration (Fig. 4A) and reaction time (Fig. 4B). The enzyme was highly active on phosphonoacetic acid and catalyzed the liberation of Pi most efficiently in the alkaline $\mathrm{pH}$ region (Fig. 5). Thus, the catalytic properties of the C-P bond cleavage

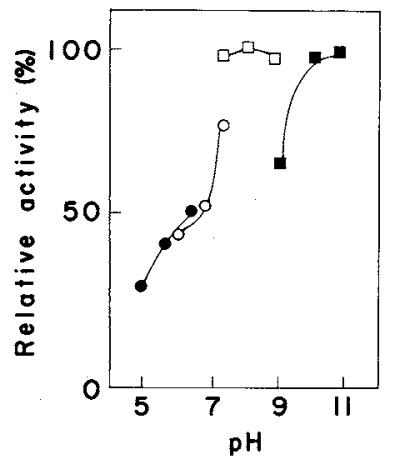

Fig. 5. Effect of $\mathrm{pH}$ on the $\mathrm{C}-\mathrm{P}$ Bond Cleavage Enzyme Activity.

The activity was determined with phosphonoacetic acid as a substrate. Other conditions were the same as those under Materials and Methods, except that various buffers were used, at $0.1 \mathrm{M}$. The activity at $\mathrm{pH} 8.0$ was taken as $100 \%$ - - acetate buffer; - $-\mathrm{HEPES} / \mathrm{NaOH}$ buffer; $-\square-$, Tris/HCl buffer; - - , glycine/KOH buffer. enzyme induced in the absence of $\mathrm{Pi}$ were almost the same as those of that formed in the presence of phosphonoacetic acid. ${ }^{9)}$ The gene for the $\mathrm{C}-\mathrm{P}$ bond cleavage enzyme in $E$. aerogenes IFO 12010 may be applicable to the breeding of herbicide-resistant crops, since the enzyme can abolish the herbicidal effect of glyphosate by cleaving the $\mathrm{C}-\mathrm{P}$ bond in the compound (Fig. 4).

\section{An attempt to purify the $C-P$ bond cleavage} enzyme in $E$. aerogenes

Extracts of E. aerogenes IFO 12010 cells grown on phenylphosphonic acid as a sole source of phosphorus were fractionated on DEAE-cellulose (Fig. 6A) and Sephadex G150 (Fig. 6B) columns as described under Materials and Methods. The $\mathrm{C}-\mathrm{P}$ bond clea-

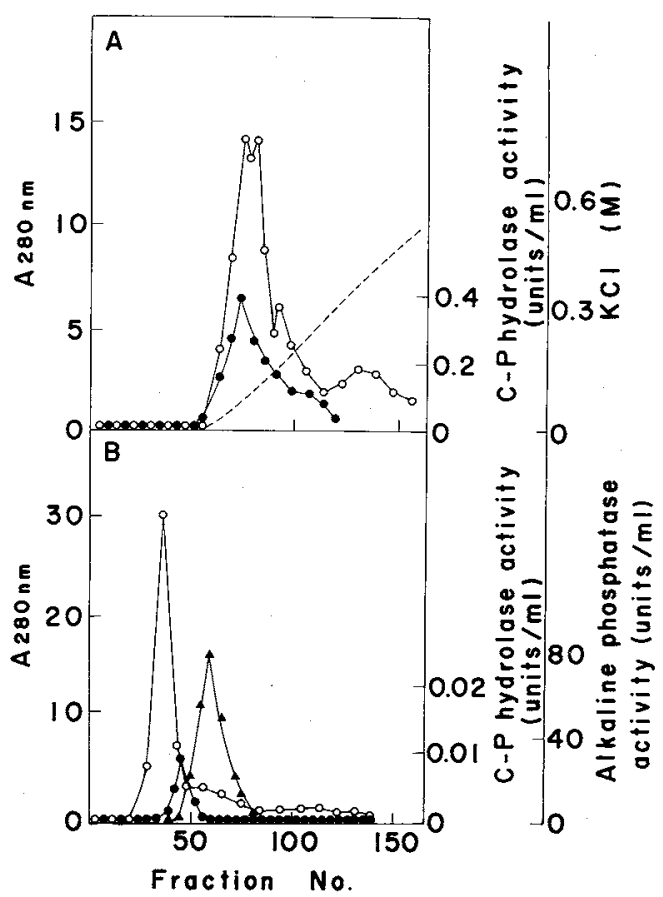

Fig. 6. Fractionation of the C-P Bond Cleavage Enzyme by Column Chromatographies.

The operation conditions for the DEAE-cellulose $[\mathrm{A}]$ and Sephadex G-150 [B] columns are given under Materials and Methods. The activity of the C-P bond cleavage enzyme was determined with phosphonoacetic acid as a substrate. $-\mathrm{O}-$, absorbance at $280 \mathrm{~nm} ;-\mathrm{O}-\mathrm{C}-\mathrm{P}$ bond cleavage enzyme activity; - $\mathbf{-}-$, alkaline phosphatase activity; -----, $\mathrm{KCl}$ concentration. 
vage enzyme was co-eluted with alkaline phosphatase, at approximately $0.1 \mathrm{M} \mathrm{KCl}$, from the DEAE-cellulose column. However, the enzyme was successfully separated from alkaline phosphatase on the Sephadex G-150 column, although there was a significant loss of its activity.

Thus, we could detect the activity of a $\mathrm{C}-\mathrm{P}$ bond cleavage enzyme in cell free extracts of $E$. aerogenes IFO 12010. As to the $\mathrm{C}-\mathrm{P}$ bond cleavage in phosphonoacetic acid, we first thought that phosphonoacetic acid is reduced to phosphonoacetaldehyde and then the $\mathrm{C}-\mathrm{P}$ bond is cleaved by an enzyme, "phosphonatase", as was assumed for the C-P bond cleavage in 2-aminoethylphosphonic acid. ${ }^{14)}$ However, the enzyme we found in $E$. aerogenes IFO 12010 requires no cofactors for its catalytic function. Furthermore, "phosphonatase" was shown to be inactive on alkyl- and phenylphosphonic acids. ${ }^{14)}$ Therefore, the $\mathrm{C}-\mathrm{P}$ bond cleavage enzyme we found in $E$. aerogenes IFO 12010 is different from "phosphonatase," although the occurrence of the latter enzyme has not been confirmed in E. aerogenes IFO 12010.

Wackett et al. ${ }^{13)}$ suggested that certain microorganisms contain an enzyme that catalyzes $\mathrm{C}-\mathrm{P}$ bond cleavage in various phosphonic and phosphinic acids, and they named the enzyme "C-P lyase." The enzyme we found in $E$. aerogenes IFO 12010, however, seems to catalyze the hydrolysis of the C-P bonds in phosphonic (and possibly phosphinic) acids, and thus should be classified as a hydrolase, not a lyase. We propose to call the enzyme a "Carbon-phosphorus (C-P) hydrolase" until the reaction mechanism of the enzyme has been fully elucidated. Anyway, this is the first report of a microbial "C-P hydrolase" that hydrolyzed C-P bonds in alkyl- and phenylphosphonic acids.

Acknowledgments. We would like to thank Monsanto Japan Co., Ltd., for supplying us with the herbicide, glyphosate.

\section{References}

1) L. D. Zeleznick, T. C. Meyers and E. B. Titchener, Biochim. Biophys. Acta, 78, 546 (1963).

2) A. M. Cook, C. G. Daughton and M. Alexander, $J$. Bacteriol., 133, 85 (1978).

3) A. M. Cook, C. G. Daughton and M. Alexander, Biochem. J., 184, 453 (1979).

4) C. G. Daughton, A. M. Cook and M. Alexander, J. Agric. Food. Chem., 27, 1375 (1979).

5) C. G. Daughton, A. M. Cook and M. Alexander, FEMS Microbiol. Lett., 5, 91 (1979).

6) C. G. Daughton, A. M. Cook and M. Alexander, Appl. Environ. Microbiol., 37, 605 (1979).

7) D. L. Shinabarger, H. D. Braymer and A. D. Larson, Appl. Environ. Microbiol., 48, 1049 (1984).

8) L. P. Wackett, S. L. Shames, C. P. Venditti and C. T. Walsh, J. Bacteriol., 169, 710 (1987).

9) K. Murata, N. Higaki and A. Kimura, Biochem. Biophys. Res. Commun., 157, 190 (1988).

10) K. Murata, T. Uchida, K. Tani, J. Kato and I. Chibata, Agric. Biol. Chem., 44, 61 (1980).

11) C. H. Fiske and Y. Subbarow, J. Biol. Chem., 66, 375 (1925).

12) O. H. Lowry, N. J. Rosebrough, A. L. Farr and R. J. Randall, J. Biol. Chem., 193, 265 (1951).

13) L. P. Wackett, B. L. Wanner, C. P. Venditti and C. T. Walsh, J. Bacteriol., 169, 1753 (1987).

14) J. M. La Nauze, H. Rosenberg and D. C. Shaw, Biochim. Biophys. Acta, 212, 332 (1970). 